\title{
Cervical lipomyelomeningocele: case Illustration
}

\author{
D. Gürkanlar and *M. Gonul
}

Akdeniz University School of Medicine, Department of Neurosurgery Antalya, Turkey. *Ankara Numune Hospital, Department of Dermatology Ankara, Turkey.

\begin{abstract}
Summary
Cervical lipomyelomeningocele is a rare congenital spinal pathology. Lipomyelomeningocele is the commonest cause of congenital tethering, which causes neurological deterioration due to the conus medullaris and root ischemia. Early intervention is recommended even in cases with normal neurological examinations in order to prevent deterioration but our patient with cervical lipomyelomeningocele had a normal neurological examination despite his age (22 year-old) and had no urodynamic dysfunction.
\end{abstract}

KEY WORDS: Lipomyelomeningocele. Cervical. Occult spinal dysraphism.

\section{Lipomielomeningocele cervical. Caso clínico}

\section{Resumen}

El lipomielomeningocele cervical es una patología raquídea congénita rara. El lipomielomeningocele es la causa más frecuente de anclaje medular, que da lugar a deterioro neurológico, debido a isquemia del cono medular y de las raíces. Se recomienda la intervención precoz, incluso en casos con examen neurológico normal, con el fin de prevenir un deterioro, pero nuestro paciente con lipomielomeningocele cervical tenía un examen neurológico normal, a pesar de su edad (22 años) y no tenía ninguna disfunción urinaria.

PALABRAS CLAVE: Lipomielomeningocele. Cervical. Disrafismo espinal oculto.

\section{Introduction}

Lipomyelomeningocele is a type of congenital occult spinal dysraphism consisting of the presence of lipomatous tissue attached to the dorsal spinal cord, which protrudes

Recibido: 29-11-06. Aceptado: 6-06-07 though a spinal defect along with the menings or spinal cord to form a posterior mass under the skin, usually in the lumbosacral region. Neural ectoderm separates from the cutaneous ectoderm and periaxial mesoderm comes in intact with the unfused ventral neural ectoderm. The mesoderm then differentiates into fatty tissue, thus preventing the neural canal and the posterior aspect of the spine from fusing ${ }^{4,5}$.

Lipomyelomeningocele is the commonest cause of congenital tethering and causes neurological deterioration due to the conus medullaris and root ischemia ${ }^{1}$.

Here we presented a 22 year-old patient harboring a lipomyelomeningocel in the cervical region without any neurological deficit and tethered cord.

\section{Case}

A 22 year-old man suffering from a posterior mass in the cervical region was admitted to our out-patient clinic (Figure 1). Neurological examination of the patient was unremarkable and he had no urinary dysfunction. Plain xray films of the cervical vertebrae revealed C5-6 posterior fusion defect (Figure 2).The magnetic resonance imaging (MRI) of the cervical spine revealed a lipomyelomeningocel at C6 level ( Figure 3).

The patient was operated under general anesthesia in prone position and the lipomyelomeningocele was corrected without any complication. Postoperative neurological examination of the patient was unremarkable.

\section{Discussion}

The lipomyelomeningocele rate has been estimated to be 2,5 per 10000 births $^{5}$. Their occurrence in the cervical region is even rarer $^{6}$. The defect is more commonly found in females ${ }^{2}$. An autosomal inheritance is also suggested for lipomyelomeningocele ${ }^{3}$.

Cervical and upper thoracic myelomeningoceles account for only $1-5 \%$ of all spinal dysraphism and lipomyelomeningocele as an additional congenital spinal pathology is very rare $^{6}$. Although lipomyelomeningocele 


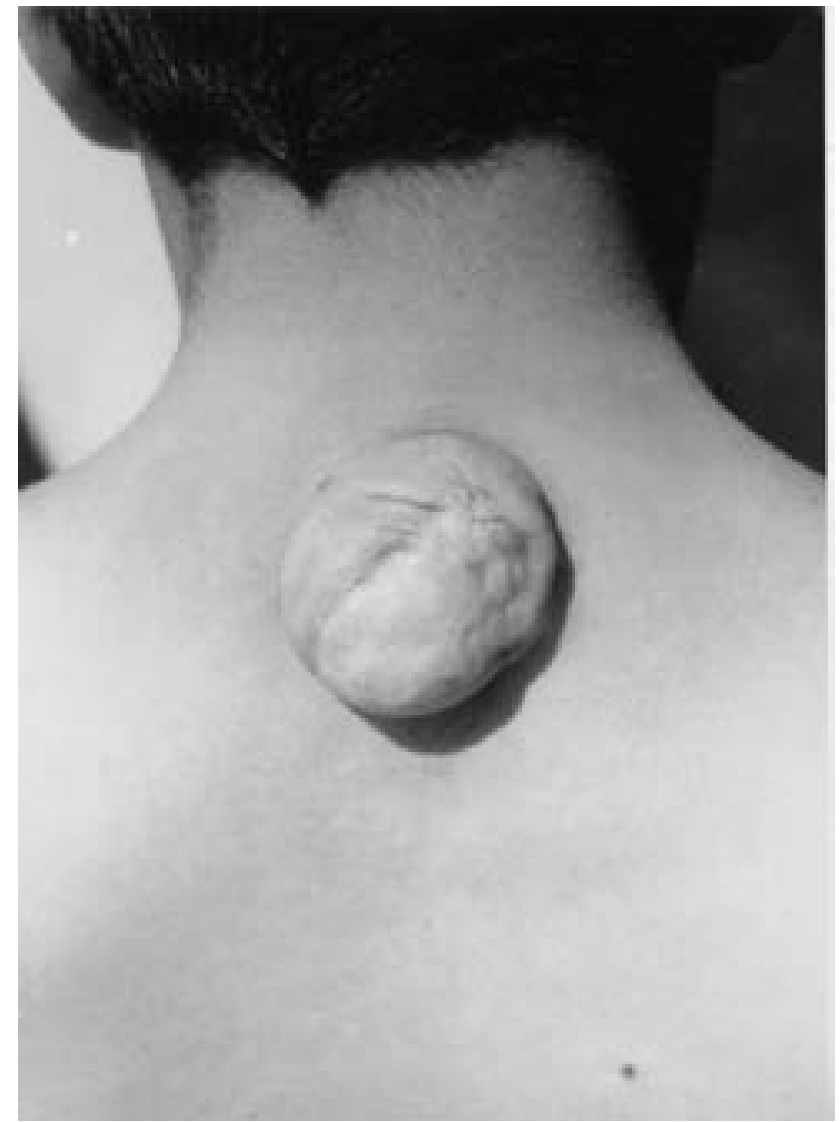

Figure 1. Our patient with cervical lipomyelomeningocele.

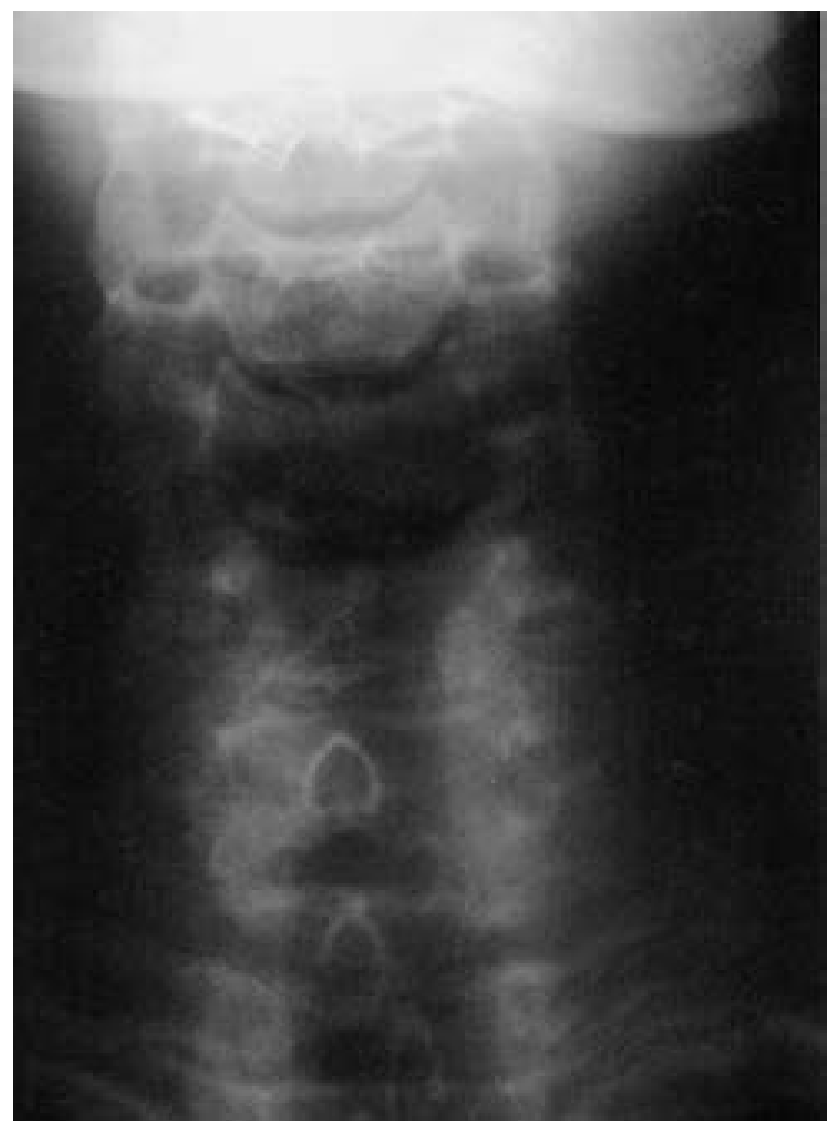

Figure 2. Cervical plain x-ray film showing C5 and C6 posterior fusion defect.

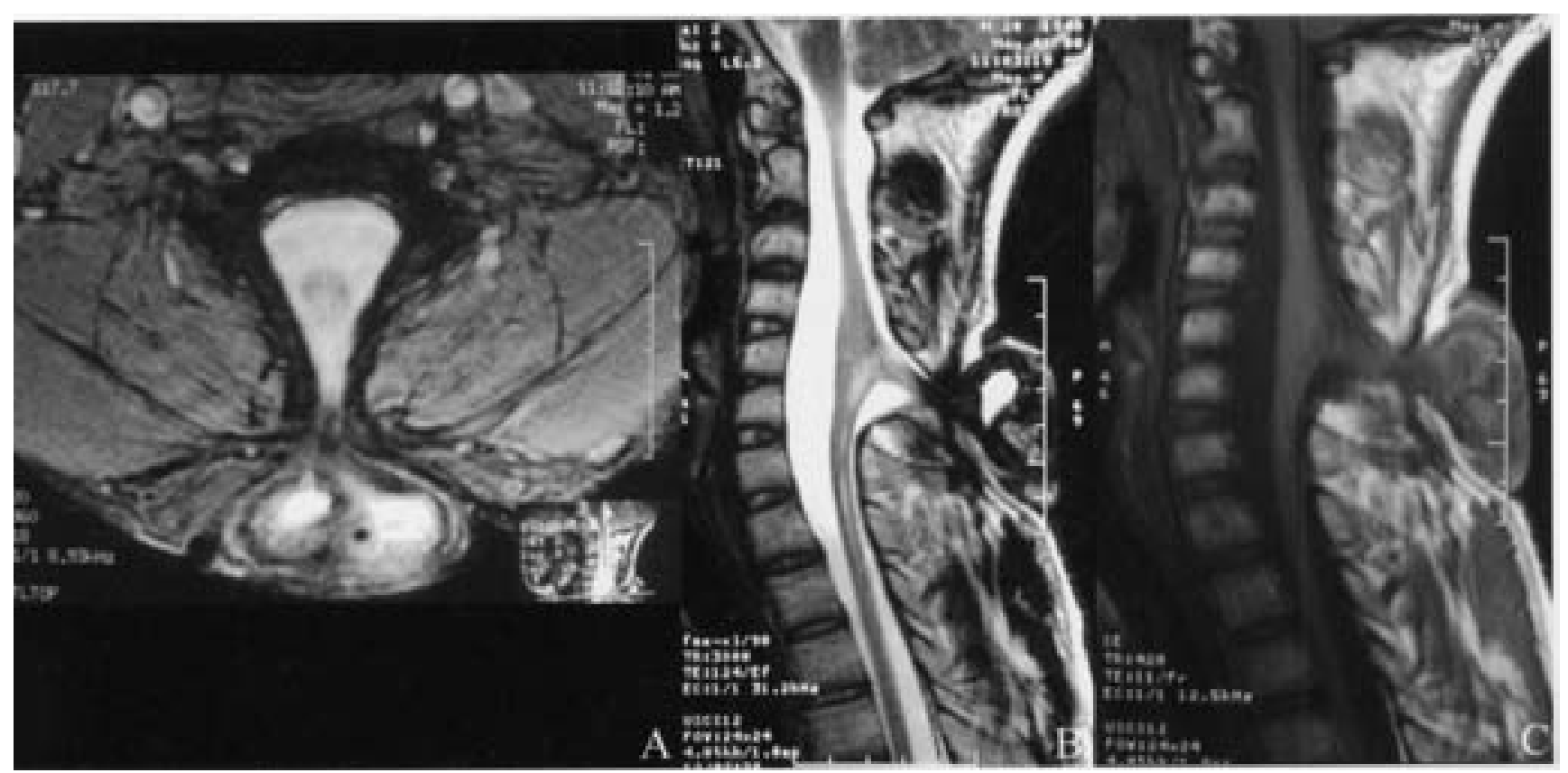

Figure 3. MRI revealing lypomyelomeningocele at C6 level. 
is the commonest cause of tethering, our patient was not harboring a tethered cord and had no urologic dysfunction ${ }^{1}$. Unless other significant spinal anomalies exist, such as a tethered cord, the risk of voiding disorders and upper tract deterioration is minimal ${ }^{7}$. Although early intervention is recommended even in cases with normal neurological examinations in order to prevent deterioration ${ }^{8}$, our patient was 22 years old and still had a normal neurological examination probably due to the lack of an additional significant spinal pathology.

It has been 5 years since we have operated the patient, and we are still following the patient's urodynamic functions because deterioration can occur up to 8 years postoperatively ${ }^{8}$.

\section{Acknowledgement}

This study was supported by Akdeniz University Research Foundation.

\section{References}

1. Cochrane, D.D., Finley, C., Kestle, J., Steinbok, P.: The patterns of late deterioration in patients with transitional lipmyelomeningocele. Eur J Pediatr Surg 2000; 10 (Suppl I) : 13-17.

2. Kanev, P.M., Bierbrauer, K.S.: Reflections on the natural history of lipomyelomeningocele. Pediatr Neurosurg 1995; 22: $137-140$.

\section{Comentario al trabajo Cervical lipomyelomeningocele: case Illustration de Gürkanlar and col.}

We read with great interest the article bu Gurkanlar and al, entitled "Cervical lipomyelomeningocele". The author describes a fatty mass starting under the skin of the child's back, in the cervical midline line. The mass extended inward to the spinal canal and was covered by skin and visible from outside. The two biggest problems lipomyelomeningoceles have in children are: The spinal cord is stuck (fixed) to the fatty mass and the fatty mass puts pressure on the spinal cord. The defect happens early in the mother's pregnancy, (about the fourth to sixth week) and has no known cause. Unlike a mielomeningocele, it does not have a genetic component nor it is due to a lack of folic acid during pregnancy. The authors describe very well a rare cause of cervical lipomyelomeningocele.

A. Kaen

R.D.Lobato

Madrid
3. Kannu, P., Furneaux, C., Aftimos, S.: Familial lipomyelomeningocele. A further report. American Journal of Medical Genetics 2005; 132A: 90-92.

4. McLone, D.G.: The biological resolution of malformations of the central nervous system. Neurosurgery 1998; 43: 1375-1380.

5. McLone, D.G., Thompson, D.N.: Lipomas of the spine. In McLone DG, editor. Pediatric neurosurgery: surgery of the developing nervous system. $4^{\text {th }}$ ed. Philadelphia 2001: WB Saunders. pp. 289-301.

6. Perez, L.M., Waxman, S.W., Webster, G.D.: Urologic management of the patient with spinal dysraphism. In Textbook of Genitourinary Surgery, $2^{\text {nd }}$ ed. Edited by H.N. Whitfield, W.F. Hendry, R.S. Kirby et al. Oxford 1998: Blackwell Science LTD, pp. 926-936.

7. Perez, L.M., Wilbanks, J.T., Joseph, D.B., Oakes, J.W.: Urological outcome of patients with cervical and upper thoracic myelomeningocele. J Urol 2000;164: 962964.

8. Wu, H., Kogan, B.A., Baskin, L.S., Edwards, M.S.B.: Long-term benefits of early neurosurgery for lipomyelomeningocele. J Urol 1998;160: 511-514.

Gürkanlar, D.; Gonul, M.: Cervical lipomyelomeningocele: case Illustration. Neurocirugía 2007; 18: 505-507.

Correspondence: Doğa Gürkanlar. M.D. Yeşilbahçe Mah. Portakalçiçeği Bulvari. 1447 sk. B.Gürkanlar Apt. 3/11. Antalya/ Türkiye. 